Abstracta Iranica Abstranica

Revue bibliographique pour le domaine irano-aryen

Volume 32-33 | 2013

Comptes rendus des publications de 2009-2010

\title{
Daniel M. Friedenberg. Sasanian Jewry and Its Culture. A Lexicon of Jewish and Related Seals
}

\section{Samra Azarnouche}

\section{(2) OpenEdition}

12 Journals

\section{Édition électronique}

URL : http://journals.openedition.org/abstractairanica/40489

DOI : 10.4000/abstractairanica.40489

ISSN : 1961-960X

Éditeur:

CNRS (UMR 7528 Mondes iraniens et indiens), Éditions de l'IFRI

\section{Édition imprimée}

Date de publication : 1 décembre 2013

ISSN : 0240-8910

Référence électronique

Samra Azarnouche, «Daniel M. Friedenberg. Sasanian Jewry and Its Culture. A Lexicon of Jewish and Related Seals », Abstracta Iranica [En ligne], Volume 32-33 | 2013, document 152, mis en ligne le 01 juillet 2016, consulté le 26 septembre 2020. URL : http://journals.openedition.org/abstractairanica/ 40489 ; DOI : https://doi.org/10.4000/abstractairanica.40489

Ce document a été généré automatiquement le 26 septembre 2020

Tous droits réservés 


\title{
Daniel M. Friedenberg. Sasanian Jewry and Its Culture. A Lexicon of Jewish and Related Seals
}

\author{
Samra Azarnouche
}

\section{RÉFÉRENCE}

Daniel M. Friedenberg. Sasanian Jewry and Its Culture. A Lexicon of Jewish and Related Seals. Urbana - Chicago, University of Illinois Press, 2009, 74 p.

1 En se référant essentiellement aux travaux de Sh. Shaked sur les sceaux juifs (1977, 1981, 1995), l'A. publie 57 sceaux (dont seule une demie douzaine n'a pas été présentée auparavant) qu'il classe selon plusieurs types iconographiques : les deux symboles du Temples (le loulav et l'etrog), la ligature d'Isaac, des portraits et des animaux, des armoiries, Daniel et la fosse aux lions, et les sceaux inscrits seulement du nom de leur propriétaire. Selon l'A., certains thèmes témoignent de l'assimilation de la culture religieuse juive à la culture sassanide, or les exemples fournis révèlent une connaissance très imparfaite de cette dernière et les références systématiques au zoroastrisme laissent à désirer.

\section{AUTEURS}

SAMRA AZARNOUCHE

Paris 